\title{
Increased Levels of Interleukin-33 and Thymic Stromal Lymphopoietin in Exhaled Breath Condensate in Chronic Bronchial Asthma
}

\author{
Joanna Glück Barbara Rymarczyk Mirosława Kasprzak Barbara Rogala \\ Clinical Department of Internal Diseases, Allergology and Clinical Immunology, Medical University of Silesia, \\ Katowice, Poland
}

\section{Key Words}

Asthma - Epithelium - Exhaled breath condensate .

Interleukin-33 · Thymic stromal lymphopoietin

\begin{abstract}
Background: Epithelium-derived cytokines such as thymic stromal lymphopoietin (TSLP), interleukin (IL)-25, and IL-33 are important contributors to inflammation in asthma. Exhaled breath condensate (EBC) is a noninvasive method used to assess the inflammation of airways. Our aim was to assess the levels of TSLP, IL-25, IL-33, and its receptor ST2I/ IL-1 R4 in EBC in patients with asthma and to correlate these with serum levels and asthma control. Methods: EBC and serum levels of TSLP, IL-25, IL-33, and ST2I/IL-1 R4 were measured in 44 patients with chronic bronchial asthma ( 14 in the uncontrolled phase) and 19 healthy control participants. Results: EBC levels of IL-33 and TSLP and serum levels of IL-33 were statistically higher in patients with asthma than in controls. IL-25 and ST2I/IL-1 R4 were present in EBC at barely detectable levels and were not analyzed. The EBC and serum levels of all studied mediators did not differ between controlled and uncontrolled asthma patients, except for the serum level of ST2I/IL-1 R4, which was higher in uncontrolled asthma. There were no correlations between serum and EBC
\end{abstract}

levels of TSLP and IL-33 or between either serum and EBC levels and the forced expiratory volume in $1 \mathrm{~s}$ or the total IgE level. Conclusions: Higher levels of IL-33 and TSLP in EBC provide evidence supporting a role for these mediators in asthma. Their levels do not discriminate between controlled and uncontrolled asthma. The local reaction within the epithelium is independent of the systemic reaction.

(c) 2016 S. Karger AG, Base

\section{Introduction}

Bronchial asthma is a chronic inflammatory disease caused by interactions between genetic and environmental factors. More and more data suggest that the pathomechanism of allergic diseases and asthma originates in the epithelium. The epithelium is immunologically active, and it is considered to be an important tissue in allergic reactions because it is the first line of protection against allergens, microbes, and noxious agents and it is a barrier between the environment and the parenchyma $[1,2]$. Moreover, aberrant expression of various genes such as the Th2-induced genes POSTN, SeRPINB2, and CLCA1 within the epithelium has been proposed to be an important contributor to allergic reactions [3]. It has also

\section{KARGER}

E-Mail karger@karger.com

www.karger.com/iaa
C 2016 S. Karger AG, Basel

$1018-2438 / 16 / 1691-0051 \$ 39.50 / 0$
Correspondence to: Dr. Joanna Glück

Clinical Department of Internal Diseases, Allergology and Clinical Immunology Medical University of Silesia

ul. Ceglana 35, PL-40-952 Katowice (Poland)

E-Mail joagluck@mp.pl 
Table 1. Patient characteristics

\begin{tabular}{|c|c|c|}
\hline & $\begin{array}{l}\text { Asthma } \\
\text { patients } \\
(\mathrm{n}=44)\end{array}$ & $\begin{array}{l}\text { Controls } \\
(\mathrm{n}=19)\end{array}$ \\
\hline Age $^{\mathrm{a}}$, years & $43(33-54)$ & $44(38-56)$ \\
\hline Male/female ratio & $8 / 35$ & $8 / 9$ \\
\hline $\mathrm{FEV}_{1}, \%$ predicted & $86(72-96)$ & n.a. \\
\hline $\mathrm{FEV}_{1} / \mathrm{FVC}$ & $78(72-82)$ & n.a. \\
\hline $\begin{array}{l}\text { Ratio of controlled/uncontrolled } \\
\text { asthma patients }\end{array}$ & $30 / 14$ & n.a. \\
\hline Inhalant allergen sensitization & $22(50)$ & n.a. \\
\hline Serum total IgE, IU/ml & $82(25-433)$ & n.a. \\
\hline Smokers & 0 & 0 \\
\hline Use of asthma controllers & & n.a. \\
\hline $\begin{array}{l}\text { Inhaled corticosteroids } \\
\quad<400 \mu \mathrm{g} \text { BUD }\end{array}$ & $8(18)$ & \\
\hline $400-800 \mu \mathrm{g}$ BUD & $17(39)$ & \\
\hline$>800 \mu \mathrm{g}$ BUD & $19(43)$ & \\
\hline aLTR & $16(36)$ & \\
\hline LABA & $24(54)$ & \\
\hline Theophylline & $6(13)$ & \\
\hline
\end{tabular}

Values are shown as medians (IQR) or numbers (\%). n.a. = Not applicable; BUD = budesonide; aLTR = antileukotrienes; LABA = long-acting $\beta$-mimetics. ${ }^{a}$ Values are comparable in asthma patients and controls.

been suggested that epithelial function influences the degree of Th2 type inflammation [1].

Thymic stromal lymphopoietin (TSLP), interleukin (IL)-25, and IL-33 belong to a group of epithelium-derived cytokines that link the innate and adaptive immune responses related to Th2 cytokine-mediated reactions. The roles of TSLP, IL-25, and IL-33 have been investigated in inflammatory diseases such as allergy. TSLP may promote an innate allergic response to indoor allergens such as house dust mites and cause asthma, and it is thought to be a central regulator of allergic asthma $[4,5]$. Genetic variants of TSLP have been found in children with asthma and allergic rhinitis [6]. ST2L/IL-1 R4 is an isoform of one of two receptors for IL-33. ST2 is expressed by natural killer cells, natural killer T cells, mast cells, monocytes, dendritic cells, granulocytes, and human Th2 cells, as well as nasal epithelium [7-9]. Both ST2L/IL-1 R4 and IL-33 serum levels are elevated in some allergic diseases, including acute bronchial asthma, in both children and adults [10-12]. IL-33 expression by epithelial cells and smooth muscle cells has also been observed in bronchial asthma $[13,14]$. IL-25 epithelial expression is in- creased in patients with asthma and it is associated with the Th2 response [15].

Exhaled-breath condensate (EBC) has been used to measure various markers of airway inflammation in patients with asthma. It is a simple, noninvasive, and safe method of airway sampling [16]. EBC is collected using special condensing devices that freeze the exhaled air. Nonvolatile particles from the epithelial lining fluid of the airway are thus suspended in aerosol form and can subsequently be detected $[17,18]$. To the best of our knowledge, epithelium-derived cytokines have not yet been studied in EBC. Thus, we decided to examine whether the epithelium-derived cytokines IL-25, IL-33, and TSLP and a soluble form of the IL-33 receptor ST2L/IL-1 R4 are present in detectable amounts in the EBC of patients with asthma and if there is a relationship between serum and EBC levels of these cytokines. The secondary aim of this study was to analyze whether the EBC and serum levels of the above-mentioned cytokines could be used as markers for bronchial asthma control.

\section{Materials and Methods}

We enrolled 44 patients with chronic bronchial asthma into this study. Asthma was diagnosed according to Global Initiative for Asthma (GINA) recommendations based on the clinical history, physical findings, and lung function test results [19]. Twentytwo patients (50\%) had allergic bronchial asthma, confirmed based on their clinical history, skin prick test results, and allergen-specific IgE estimation. Fourteen of the patients assessed (32\%) were in the uncontrolled phase of the disease. Partially controlled and uncontrolled asthma were diagnosed according to GINA recommendations based on the clinical picture, anamnestic data, and spirometry values [19]. The patients with bronchial asthma were allowed to use inhalant glucocorticosteroids, antileukotrienes, theophylline, and short- or long-acting $\beta_{2}$-mimetics (table 1 ).

As controls, we included 19 healthy volunteers (9 males, median age 44 years, range 37.5-55.5) with normal lung function and no signs of bronchial asthma or other systemic diseases. The precise characteristics of both groups are shown in table 1. Exclusion criteria included acute respiratory infections in the previous 4 weeks, any pathological changes in the mouth, and chronic inflammatory or malignant conditions that, in the researchers' opinion, could bias the results. EBC and blood samples were collected from all patients and controls. Skin prick tests and spirometry were performed for all patients with asthma. The Local Ethical Committee of the Medical University of Silesia approved this study. The participants provided written informed consent.

\section{EBC Collection, Exhaled Nitric Oxide Assessment, and Spirometry}

EBC was collected using an EcoScreen II Turbo condenser (Medivac, Italy) according to American Thoracic Society/European Respiratory Society recommendations [20]. EBC was collected in the morning, $2 \mathrm{~h}$ before meals. The participants used nose
Glück/Rymarczyk/Kasprzak/Rogala 
Table 2. Serum levels of IL-33, IL-25, TSLP, and ST2L/IL-1 R4 and EBC levels of IL-33 and TSLP in asthmatic patients, controlled and uncontrolled asthmatic patients, and controls

\begin{tabular}{|c|c|c|c|c|c|c|}
\hline & $\begin{array}{l}\text { Asthma } \\
\text { group }(\mathrm{n}=44)\end{array}$ & $\begin{array}{l}\text { Controlled } \\
\text { asthma }(\mathrm{n}=30)\end{array}$ & $\begin{array}{l}\text { Uncontrolled } \\
\text { asthma }(\mathrm{n}=14)\end{array}$ & $\begin{array}{l}\text { Controls } \\
(\mathrm{n}=19)\end{array}$ & $\mathrm{p}^{\mathrm{a}}$ & $\mathrm{p}^{\mathrm{b}}$ \\
\hline \multicolumn{7}{|c|}{ Serum level, $p g / m l$} \\
\hline IL-33 & $58.8(36-157)$ & $55(34-159)$ & $70(56-155)$ & $31(23-47)$ & 0.004 & 0.61 \\
\hline IL-25 & $2.285(1.21-17.45)$ & $2.1(1.2-17.2)$ & $10.2(1.3-19.2)$ & $11.1(23-47)$ & 0.058 & 0.46 \\
\hline TSLP & $77(42-129.1)$ & $66.7(40-124.9)$ & $100(54-144)$ & $45.9(34.4-65)$ & 0.054 & 0.31 \\
\hline ST2L/IL-1 R4 & $650(454.5-830.9)$ & $567(413-782)$ & $833.9(500-976)$ & $670(469-835)$ & 0.99 & 0.022 \\
\hline \multicolumn{7}{|l|}{ EBC level, $p g / m l$} \\
\hline IL-33 & $5(2.2-9)$ & $5(2.2-9)$ & $6(2.2-9.0)$ & $1.9(1.2-2.6)$ & 0.0008 & 0.55 \\
\hline TSLP & $39(23-55)$ & $41(24.8-55)$ & $31(12.5-40)$ & $13.1(10.25-23.45)$ & 0.0002 & 0.11 \\
\hline
\end{tabular}

Values are presented as medians (IQR) unless otherwise stated. ${ }^{\text {a }}$ For comparisons between the asthma group and controls. ${ }^{\mathrm{b}}$ For comparisons between the controlled and uncontrolled asthma groups.

clips and were allowed to periodically swallow saliva to maintain a dry mouth during collection. The procedure lasted $20 \mathrm{~min}$ and about $1.5 \mathrm{ml} \mathrm{EBC}$ was collected. The EBC and serum samples were stored at $-80^{\circ} \mathrm{C}$ until analyzed. Spirometry was performed using a Medgraphics CPFS/D USB spirometer (MGC Diagnostics, USA) according to European Respiratory Society standards [21].

\section{Skin Prick Tests}

Skin prick tests were performed according to European Academy of Allergy and Clinical Immunology guidelines using Allergopharma (Germany) extracts [22].

Measurement of Serum Levels of ST2L/IL-1 R4, TSLP, IL-25, and IL-33 and Serum Levels of Total and Allergen-Specific IgE

Commercial enzyme-linked immunosorbent assays were used to measure EBC and serum levels of IL-25 (Wuhan EIAAB Science, China), IL-33, ST2L/IL-1 R4, and TSLP (R\&D Systems, USA). The assays were performed using the protocols recommended by the manufacturers. The sensitivity of the assays was as follows: IL-25, 6.9 pg/ml; IL-33, 1.65 pg/ml; ST2L/IL-1 R4, 13.5 pg/ $\mathrm{ml}$, and TSLP, $9.87 \mathrm{pg} / \mathrm{ml}$. In the case of values lower than the method sensitivity limit, the samples were quantified based on extrapolation of standard curves generated for each set of samples assayed. Only the proteins that recorded a level at least half of that of the detection limit were analyzed (table 2). The proteins with a value lower than half that of the detection limit were excluded from further analyses. Total and allergen-specific IgE levels were determined using an enzyme-linked immunosorbent assay (Allergopharma).

\section{Statistical Analysis}

Results are expressed as median values with interquartile ranges (IQR). We used nonparametric tests (Mann-Whitney U rank sum test, Kruskal-Wallis test, and Spearman's correlation test) because of the nonnormal distribution of the data. All analyses were performed with the software package STATISTICA 10 (Statsoft Polska, Poland). $\mathrm{p}<0.05$ was considered statistically significant.

IL-33 and TSLP in EBC in Asthma

\section{Results}

IL-25 and ST2L/IL-1R4 levels were under the limit of detection in almost all of the EBC samples. The values were quantified based on extrapolation of standard curves generated for each set of samples assayed; however, because of the very low values, and possibly poor reliability, these data were not analyzed further and comparisons were not performed (table 2). Values below half of the minimal detection limit were found in 2 patients for IL-33 $(<0.825 \mathrm{pg} / \mathrm{ml})$ and in 2 patients for TSLP $(<4.935 \mathrm{pg} / \mathrm{ml})$. These data were excluded from further analyses.

EBC levels of IL-33 and TSLP were statistically higher in patients with asthma than in controls (fig. 1,2). The serum level of IL-33 was statistically higher in patients with asthma than in controls $[58.8 \mathrm{pg} / \mathrm{ml}$ (IQR 36-157) vs. $31 \mathrm{pg} / \mathrm{ml}$ (IQR 23-47), respectively, $\mathrm{p}=0.004$ ] (fig. 3). There was a trend for higher serum levels of TSLP [77 pg/ $\mathrm{ml}$ (IQR 42-129.1) vs. $45.9 \mathrm{pg} / \mathrm{ml}$ (IQR 34.4-65), respectively, $\mathrm{p}=0.054]$ and IL-25 $[2.285 \mathrm{pg} / \mathrm{ml}$ (IQR $1.21-$ $17.45)$ vs. $11.1 \mathrm{pg} / \mathrm{ml}$ (IQR 23-47), respectively, $\mathrm{p}=$ 0.058 ] in patients with asthma compared to controls, but this was not statistically significant (table 2 ). There were no significant correlations between serum and EBC levels of TSLP and IL-33 in asthma patients $\left(r_{s}=0.03\right.$ and 0.137 , respectively) or controls $\left(r_{s}=0.104\right.$ and 0.23 , respectively).

EBC levels of IL-33 and TSLP and serum levels of IL25, IL-33, and TSLP did not significantly differ between the patients with controlled and uncontrolled asthma. Serum levels of ST2L/IL-1 R4 were statistically higher in patients with uncontrolled asthma $[833.9 \mathrm{pg} / \mathrm{ml}$ (IQR

Int Arch Allergy Immunol 2016;169:51-56 DOI: $10.1159 / 000444017$ 


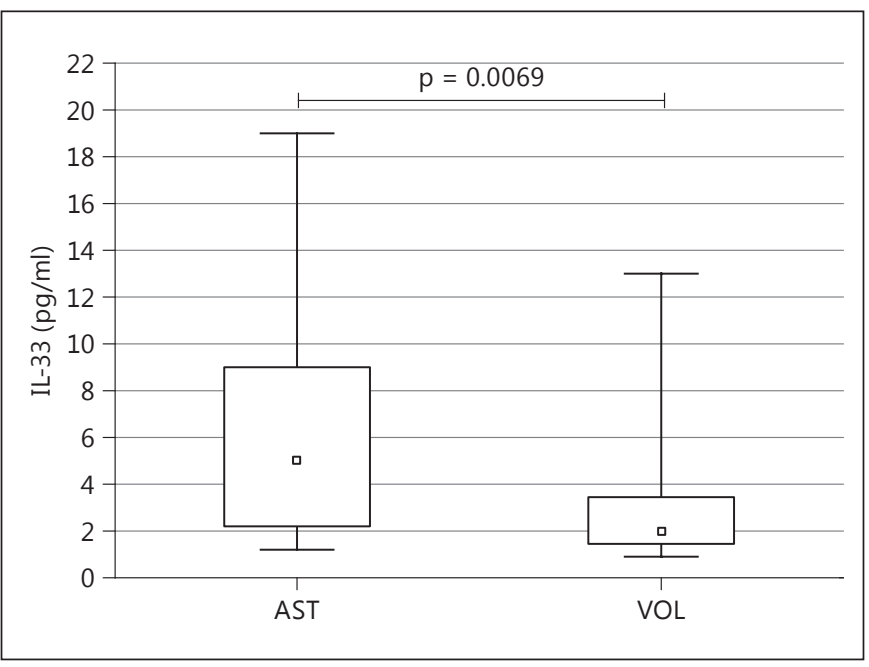

Fig. 1. IL-33 levels in EBC from patients with asthma and healthy controls. The square indicates the median value, the box indicates the IQR, and the whiskers indicate the total range. AST = Patients with asthma; $\mathrm{VOL}=$ controls.

500-976) vs. $567 \mathrm{pg} / \mathrm{ml}$ (IQR 413-782), respectively]. The serum and EBC levels of TSLP and IL-33 did not correlate with the forced expiratory forced expiratory volume in $1 \mathrm{~s}\left[\mathrm{FEV}_{1} ; \mathrm{r}_{\mathrm{s}}=0.05\right.$ (TSLP in serum), 0.31 (IL-33 in serum), -0.11 (TSLP in EBC), and 0.15 (IL-33 in EBC)] or the total serum level of IgE $\left[\mathrm{r}_{\mathrm{s}}=0.26\right.$ (TSLP in serum), -0.39 (IL-33 in serum), 0.01 (TSLP in EBC), and $-0,33$ (IL-33 in EBC); Spearman's correlation test].

The doses of inhaled glucocorticosteroids used did not interfere with serum IL-25, IL-33, ST2L/IL-1 R4, and TSLP levels or with EBC IL-33 and TSLP levels (in all comparisons $\mathrm{p}>0.05$, Kruskal-Wallis test).

\section{Discussion}

In the present study, we explored the levels of 3 epithelium-derived cytokines (i.e. IL-25, IL-33, and TSLP) and a soluble form of the IL-33 receptor ST2L/IL-1 R4 in EBC and in the serum of patients with asthma and healthy controls. We additionally compared data between patients with controlled and uncontrolled disease. Only 2 of the examined mediators, i.e. IL-33 and TSLP, were detectable in EBC in amounts greater than half of the detection limit both in asthma patients and in healthy controls. We found significantly higher EBC levels of both IL-33 and TSLP, and a significantly higher serum level of IL-33, in patients with asthma compared to healthy controls. The

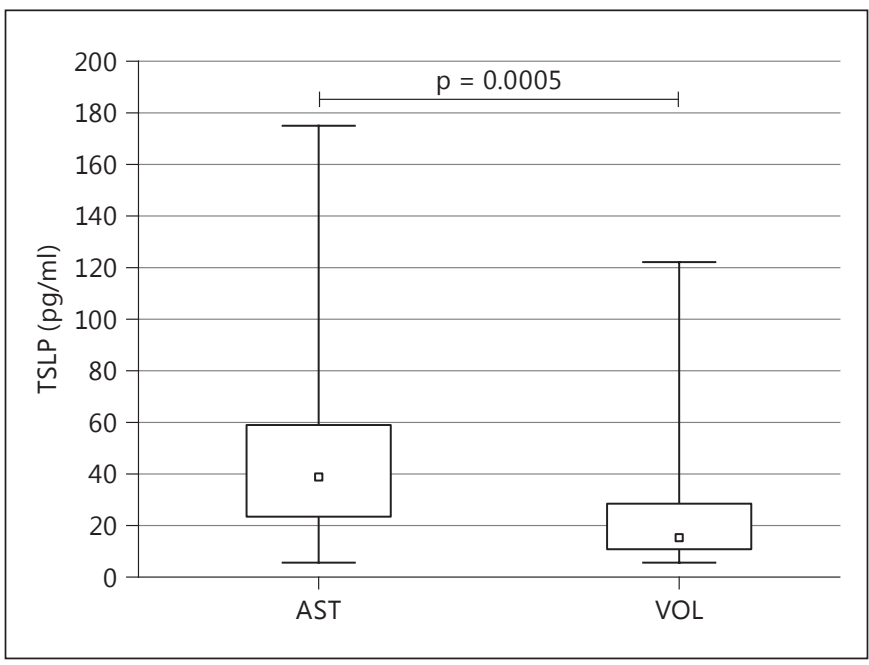

Fig. 2. TSLP levels in EBC from patients with asthma and healthy controls. The square indicates the median value, the box indicates the IQR, and the whiskers indicate the total range. AST = Patients with asthma; VOL = controls.

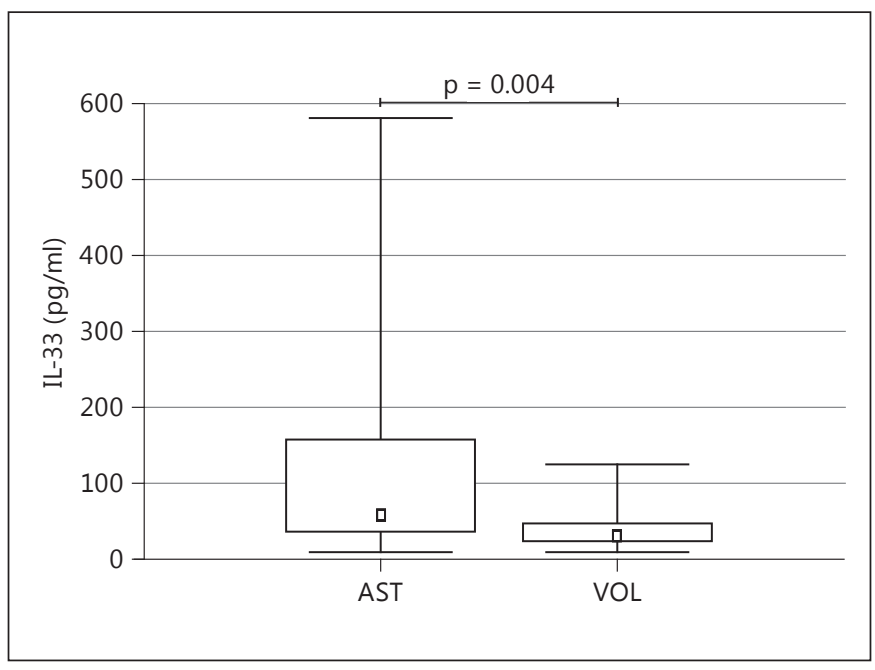

Fig. 3. IL-33 in serum from patients with asthma and healthy controls. The square indicates the median value, the box indicates the $\mathrm{IQR}$, and the whiskers indicate the total range. AST = Patients with asthma; $\mathrm{VOL}=$ controls.

values of EBC and serum levels did not differ between controlled and uncontrolled asthma.

Both IL-33 and TSLP belong to a group of epitheliumderived cytokines. Our results indicate that these two cytokines are present in EBC from patients with bronchial asthma, and that this is a stable feature regardless of the 
control level of asthma (controlled vs. uncontrolled). To the best of our knowledge, these cytokines have not previously been studied in the EBC of patients with asthma. Our results are of interest because both of the epitheliumderived cytokines, i.e. IL-33 and TSLP, are important activators of allergic inflammation and therapeutic targets for asthma. Some studies have been reported on animal models in which the therapeutic possibility of blocking IL-33 and TSLP was observed. Blockade of a receptor for TSLP by monoclonal antibodies in a cynomolgus monkey model of asthma and administration of anti-IL-33 antibodies in a murine model of asthma have both been shown to reduce allergic inflammation [23, 24]. Moreover, allergic inflammation was dramatically reduced in TSLP receptor-deficient mice, with less production of proinflammatory cytokines, such as IL-1 $\beta$, or Th-2-related cytokines, such as IL-13 and IL-33 [25]. Neutralization of TSLP with anti-TSLP monoclonal antibodies reversed allergic inflammation and inhibited airway remodeling in chronic allergen-induced asthma in mice [26]. Galactooligosaccharides have been found to suppress IL-33 expression at the site of inflammation in house dust mite-induced asthma in mice [27]. In a human study, it was recently shown that anti-TSLP antibody reduced allergen-induced bronchoconstriction and indexes of airway inflammation before and after allergen challenge [28].

IL-33 is constitutively expressed in epithelial barrier tissues. Shortly after exposure to allergens or other noxious stimulators, such as pollutants or infections, IL-33 has been shown to induce Th2 cytokine production by group 2 innate lymphoid cells and to initiate allergic inflammation. Owing to this response, IL-33 is also called the 'alarmin' cytokine $[29,30]$. We found no difference in the levels of analyzed cytokines in EBC between patients with controlled and uncontrolled asthma. These data are surprising given that during rhinovirus-induced asthma exacerbation inflammation is dependent on IL-33 [31]. There are data suggesting that some parameters found in EBC can distinguish patients with different asthma control or severity. Tomasiak-Łozowska et al. [32] examined the acid-base equilibrium in EBC and found lower $\mathrm{pH}$ values and ammonia concentrations and significantly higher levels of nitrite/nitrate in patients with unstable asthma, and they concluded that these parameters may be useful as markers of asthma severity. The same authors found higher levels of eotaxin-1 in EBC from patients with unstable asthma than in patients with stable disease and healthy controls [33]. During asthma exacerbation, the $\mathrm{pH}$ of $\mathrm{EBC}$ decreases and $\mathrm{H}_{2} \mathrm{O}_{2}, 8$-isoprostane, and cysteinyl-leukotriene concentrations increase $[17,34]$.

In our study, we found statistically higher serum levels of ST2L/IL-1 R4 in uncontrolled asthma compared to controlled asthma. However, there were no differences between either subgroup of patients and controls. Although we observed statistical significance, the clinical relevance seems to be low given that the IQR were close to each other.

In conclusion, two epithelium-derived cytokines, i.e. IL-33 and TSLP, are found at higher levels in EBC from patients with asthma compared to healthy controls, supporting the important role of these mediators in bronchial asthma. The EBC levels of these two mediators do not correlate with their serum levels, which suggest that the local epithelial reaction is independent of the systemic reaction. The levels of IL-33 and TSLP in EBC do not discriminate between controlled and uncontrolled asthma.

\section{Acknowledgement}

This study was supported by grant KNW-135-P/2/0 from the Medical University of Silesia.

\section{References}

1 Lloyd CM, Saglani S: Asthma and allergy: the emerging epithelium. Nat Med 2010;16:273274.

2 Loxham M, Davies DE, Blume C: Epithelial function and dysfunction in asthma. Clin Exp Allergy 2014;44:1299-1313.

3 Koppelman GH, Meyers DA, Howard TD, et al: Identification of PCDH1 as a novel susceptibility gene for bronchial hyperresponsiveness. Am J Respir Crit Care Med 2009;180: 929-935.
4 Watson B, Gauvreau GM: Thymic stromal lymphopoietin: a central regulator of allergic asthma. Expert Opin Ther Targets 2014;18: 771-785.

5 Iijima H, Kaneko Y, Yamada H, Yatagai Y, Masuko H, Sakamoto T, Naito T, Hirota T, Tamari M, Konno S, Nishimura M, Noguchi E, Hizawa $\mathrm{Nl}$ : A distinct sensitization pattern associated with asthma and the thymic stromal lymphopoietin (TSLP) genotype. Allergol Int 2013;62:123-130.
6 Birben E, Sahiner UM, Karaaslan C, Yavuz TS, Cosgun E, Kalayci O, Sackesen C: The genetic variants of thymic stromal lymphopoietin protein in children with asthma and allergic rhinitis. Int Arch Allergy Immunol 2014;163:185-192.

$7 \mathrm{Xu}$ D, Chan WL, Leung BP, Huang Fp Wheeler R, Piedrafita D, Robinson JH, Liew FY: Selective expression of a stable cell surface molecule on type 2 but not type 1 helper $\mathrm{T}$ cells. J Exp Med 1998;187:787-794. 
8 Kamekura R, Kojima T, Takano K, Go M, Sawada N, Himi T: The role of IL-33 and its receptor ST2 in human nasal epithelium with allergic rhinitis. Clin Exp Allergy 2011;42: 218-228

9 Milovanovic M, Volarevic V, Radosavljevic I, Pejnovic N, Arsenijevic N, Lukic ML: IL-33/ ST2 axis in inflammation and immunopathology. Immunol Res 2012;52:89-99.

10 Glück J, Rymarczyk B, Rogala B: Serum IL-33 but not ST2 level is elevated in intermittent allergic rhinitis and is a marker of the disease severity. Inflamm Res 2012;5:547-550.

11 Oshikawa K, Kuroiwa K, Tago K, Iwahana H, Yanagisawa K, Ohno S, Tominaga SI, Sugiyama Y: Elevated soluble ST2 protein levels in sera of patients with asthma with an acute exacerbation. Am J Respir Crit Care Med 2001; 164:277-281.

12 Ali M, Zhang G, Thomas WR, McLean CJ, Bizzintino JA, Laing IA, Martin AC, Goldblatt J, Le Souëf PN, Hayden CM: Investigations into the role of ST2 in acute asthma in children. Tissue Antigens 2009;73:206-212.

13 Préfontaine D, Nadigel J, Chouiali F, Audusseau S, Semlali A, Chakir J, Martin JG, Hamid Q: Increased IL-33 expression by epithelial cells in bronchial asthma. J Allergy Clin Immunol 2010;125;752-754.

14 Préfontaine D, Lajoie-Kadoch S, Foley S, Audusseau S, Olivenstein R, Halayko AJ, Lemière C, Martin JG, Hamid Q: Increased expression of IL-33 in severe asthma: evidence of expression by airway smooth muscle cells. J Immunol 2009;183:5094-5103.

15 Cheng D, Xue Z, Yi L, Shi H, Zhang K, Huo X, Bonser LR, Zhao J, Xu Y, Erle DJ, Zhen Gl: Epithelial interleukin-25 is a key mediator in th2-high, corticosteroid-responsive asthma. Respir Crit Care Med 2014;190:639-648.

16 Munoz X, Bustamante V, Lopez-Campos J-L, Cruz M-J, Barreiro E: Usefulness of noninvasive methods for the study of bronchial inflammation in the control of patients with asthma. In Arch Allergy Immunol 2015;166: $1-12$.

17 Loukides S, Kontogianni K, Hillas G, Horvath I: Exhaled breath condensate in asthma: from bench to bedside. Curr Med Chem 2011;18: 1432-1443.
18 Antczak A, Górski P: Markers of pulmonary diseases in exhaled breath condensate. Int J Occup Med Environ Health 2002; 15:317323.

19 Global Initiative for Asthma: Global strategy for asthma management and prevention. 2010. http://www.ginasthma.org/.

20 Horváth I, Hunt J, Barnes PJ, Alving K, Antczak A, Baraldi E: ATS/ERS Task Force on exhaled breath condensate: methodological recommendations and unresolved questions. Eur Respir J 2005;26:523-548.

21 Miller MR, Hankinson J, Brusasco V, et al: Standardisation of spirometry. Eur Respir J 2005:26:319-338.

22 Dreborg S, Frew A: Position papers: allergen standardization and skin tests. Allergy 1993; 48:9-82.

23 Cheng DT, Ma C, Niewoehner J, Dahl M, Tsai A, Zhang J, Gonsiorek W, Apparsundaram S, Pashine A, Ravindran P, Jung J, Hang J, Allard J, Bitter H, Tribouley C, Narula S, Wilson S, Fuentes MEDahl M, Tsai A, Zhang J, Gonsiorek W, Apparsundaram S, Pashine A, Ravindran P, Jung J, Hang J, Allard J, Bitter H, Tribouley C, Narula S, Wilson S, Fuentes ME: Thymic stromal lymphopoietin receptor blockade reduces allergic inflammation in a cynomolgus monkey model of asthma. J Allergy Clin Immunol 2013;132:455-462.

24 Kim YH, Yang TY, Park C-S, Ahn SH, Son BK, Kim JH, Lim DH, Jang TY: Anti-IL-33 antibody has a therapeutic effect in a murine model of allergic rhinitis. Allergy 2012;49: 738-743.

25 Togbe D, Fauconnier L, Madouri F, Marchiol T, Chenuet P, Rouxel N, Ledru A, Erard F, Quesniaux V, Ryffel B: Thymic stromal lymphopoietin enhances Th2/Th22 and reduces IL-17A in protease-allergen-induced airways inflammation. ISRN Allergy 2013;7:971036.

26 Chen ZG, Zhang TT, Li HT, Chen FH, Zou XL, Ji JZ, Chen H: Neutralization of TSLP inhibit airway remodeling in a murine model of allergic asthma induced by chronic exposure to house dust mite. PLoS One 2013;8:e51268.

27 Verheijden KAT, Akbari P, Willemsen LE, Kraneveld AD, Folkerts G, Garssen J, FinkGremmels J, Braber S: Inflammation-induced expression of the alarmin interleukin $33 \mathrm{can}$ be suppressed by galacto-oligosaccharides. Int Arch Allergy Immunol 2015;167:127-136.

28 Gauvreau GM, O’Byrne PM, Boulet LP, Wang Y, Cockcroft D, Bigler J, FitzGerald JM, Boedigheimer M, Davis BE, Dias C, Gorski KS, Smith L, Bautista E, Comeau MR, Leigh R, Parnes JR: Effects of an anti-TSLP antibody on allergen-induced asthmatic responses. N Engl J Med 2014;370:2102-2110.

29 Bartemes KR, Kephart GM, Fox SJ, Kita H: Enhanced innate type 2 immune response in peripheral blood from patients with asthma. J Allergy Clin Immunol 2014;134:671-678.

30 Halim TY, Steer CA, Mathä L, Gold MJ, Martinez-Gonzalez I, McNagny KM, McKenzie AN, Takei F: Group 2 innate lymphoid cells are critical for the initiation of adaptive $\mathrm{T}$ helper 2 cell-mediated allergic lung inflammation. Immunity 2014;20:425-435.

31 Jackson DJ, Makrinioti H, Rana BM, Shamji BW, Trujillo-Torralbo MB, Footitt J, Jerico Del-Rosario, Telcian AG, Nikonova A, Zhu J, Aniscenko J, Gogsadze L, Bakhsoliani E, Traub S, Dhariwal J, Porter J, Hunt D, Hunt T, Hunt T, Stanciu LA, Khaitov M, Bartlett NW, Edwards MR, Kon OM, Mallia P, Papadopoulos NG, Akdis CA, Westwick J, Edwards MJ, Cousins DJ, Walton RP, Johnston SL: IL-33-dependent type 2 inflammation during rhinovirus-induced asthma exacerbations in vivo. Am J Respir Crit Care Med 2014; 190:1373-1382.

32 Tomasiak-Łozowska MM, Zietkowski Z, Przeslaw K, Tomasiak M, Skiepko R, Bodzenta-Lukaszyk A: Inflammatory markers and acid-base equilibrium in exhaled breath condensate of stable and unstable asthma patients. Int Arch Allergy Immunol 2012;159: 121-129.

33 Zietkowski Z, Tomasiak-Lozowska MM Skiepko R, Zietkowska E, Bodzenta-Lukaszyk A: Eotaxin-1 in exhaled breath condensate of stable and unstable asthma patients. Respir Res 2010;11:110-119.

34 Hüttmann E-M, Greulich T, Hattesohl A, Schmid S, Noeske S, Herr C, John G, Jörres RA, Müller B, Vogelmeier C, Koczulla AR: Comparison of two devices and two breathing patterns for exhaled breath condensate sampling. PLoS One 2011;11:e27467. 